UOT 547.447.3: 542.95

NONIL FENOLUN FORMALDEHID İL KONDENSLOŞMO MOHSULUNUN BARIUM DUZUNUN KONSERVASIYYA MAYESİNO KOMPONENT KİMİ TODQİQİ

\author{
N.Ş. Rzayeva \\ AMEA-nın akad. Y.H.Mammadaliyev adına Neft-Kimya Proseslari Institutu \\ Az1025 Bakl, Xocalı pr.30;nigar.rzayeva555@gmail.com
}

Redaksiyaya daxil olub 28.07.2018

Nonil fenolun formaldehid ilə kondenslaşmə məhsulunun $B a$ duzu alınmış, mineral yağlar və onların distillatlarına alava edilarək konservasiya mayesi kimi dəniz suyunda və 0.001\%-li $\mathrm{H}_{2} \mathrm{SO}_{4}$ məhlulunda polad-3 nümunəsinin korroziyadan müdafiasina tasiri öyranilmişdir. Osas komponent kimi T-46, T-30, T-1500, AK-15 yağlarının distillatlart və yağların özlari götürülmüşdür. Mü̈yyən edilmişdir ki, on yaxşı nəticə AK-15 yağlarında alınmışdır. Belə ki, AK-15 yağında Ba duzu 10\% kütla olduqda müdafi müddati hidrokamerada, dəniz suyunda va 0.001\%-li $\mathrm{H}_{2} \mathrm{SO}_{4}$ məhlulunda uyğun olaraq 150 sutka (davam edir) 145 va 141 sutka olmuşdur.

Açar sözlor: atmosfer korroziyası, konservasiya mayelori, mineral yağlar, alkil fenollar, alkil fenolların formaldehid ila kondenslaşma mahsulları.

\title{
GíRiş
}

Hazırda atmosfer korroziyasından müdafionin ən yaxşı üsullarından biri konservasiya mayelərinin istifadəsidir [1-2]. Atmosferin aqressiv çirkləndiricilərinin $\left(\mathrm{CO}_{2}\right.$, $\mathrm{H}_{2} \mathrm{~S}, \mathrm{SO}_{2}, \mathrm{SO}_{3}$, azot oksidləri və s.) artmasi atmosferin aqressiv təsirini artırdığından daha effektiv konservasiya mayelərinin yaradılması təlabatı dahada aktuallaşıb[3-4]. İnkişaf etmiş neft və qazçıxarma, neft və qaz emalı, kimya sənayelərinə malik Xəzəryanı ölkələrdə yüksək keyfiyyətli və geniş xammal ehtiyatlarına malik konservasiya mayelərinin istehsalı ya tamamilə yoxdur, ya da olduqca azdir.

\section{EKSPERIMENTAL HISSO}

Qeyd olunanlara əsasən biz yüksək keyfiyyətli konservasiya mayeləri hazırlamaq üçün geniş sənaye istehsalına malik nonilfenol və Bakı neftlərindən alınmış mineral yağlar və onların distillatlarından istifadə etmişik.
Ovvəlcə nonilfenol məlum metodika ilə formaldehidlə kondensləşdirilmiş, sonra kondensləşmə məhlulunun $\mathrm{Ba}$ duzu sintez olunmuşdur [5]. Alınan barium duzunun formulu belədir:<smiles>CCCCCCCCCCCCCCCCc1ccc(CCCCC)cc1Cc1cc(CCCCC)ccc1O</smiles> 
Nonilfenolun kondensləşmə reaksiyası xüsusi qarışdırıcısı olan reaktorda turş mühitdə, $\quad 0.2 \mathrm{MPa}$ təzyiqdə, $96-98^{\circ} \mathrm{C}$ temperaturda aparilib.

Kondensləşmə üçün lazım olan 37\%-li formaldehid nonilfenola nəzərən $20 \%$ götürülmüşdür. Katalizator kimi istifadə olunan xlorid turşusunun miqdarı $0.5 \%$ götürülmüşdür. Sonra kondensləşmə məhsuluna $50 \%$ miqdarında $\mathrm{T}-46$ yağı əlavə edilmişdir və kondensləşmə məhsulu $60-80^{\circ} \mathrm{C}$ də sudan ayrılmışdır. Sonra qurudulma vakuum altında aparılaraq suyun miqdarı 1\%dən çox olmayan həddə qədər azaldılmışdır.

Yağda həll olmuş kondensləşmə məhsulunun 60-65\%-i miqdarına barium hidroksid

$$
105-110^{\circ} \mathrm{C}
$$

temperaturda qarışdırılmışdır və qarışıq üzərinə 110\% T-46 yağı əlavə edilərək yağda məhlul hazırlanmışdır. Məhlul sentrufuqada ilkin təmizləmədən keçirilir, sonra 0.072-0.092 $\mathrm{MPa}-d a$ və $130-135^{\circ} \mathrm{C}$ temperaturda qurudulur və təkrar sentrufuqada təmizlənir. Alınmış barium duzunun T-46-da 39\%-li məhlulu T46, T-1500, T-30 yağlarının distillatlarına və yağların özlərinə müxtəlif miqdarda əlavə edilərək konservasiya mayesi hazırlanmış, dəniz suyunda və $0.001 \%-\mathrm{li} \quad \mathrm{H}_{2} \mathrm{SO}_{4}$ məhlulunda polad-3 nümunəsini korroziyadan müdafiə etməsi tədqiq olunmuşdur.

Alınan nəticələr cadvəl 1 və cədvəl 2-də verilir.

Cədvəl 1. Nonilfenolun hidroksil qrupu saxlayan Ba duzunun mineral yağların distillatlarında məhlullarının konservasiya mayesi kimi sınaqlarının nəticələri.

\begin{tabular}{|c|c|c|c|}
\hline \multirow[b]{2}{*}{ Kompozisiyalar } & \multirow{2}{*}{$\begin{array}{l}\text { Duzun qatılığ1, } \\
\text { \% kütlə }\end{array}$} & \multicolumn{2}{|c|}{ Korroziyadan müdafiə müddəti, sutka } \\
\hline & & Dəniz suyunda & $\begin{array}{c}0.001 \%-\mathrm{li}_{2} \mathrm{SO}_{4} \\
\text { məhlulunda }\end{array}$ \\
\hline \multirow{4}{*}{ 1. T-46 yağının distillatında } & 4.0 & 93 & 90 \\
\hline & 5.0 & 93 & 90 \\
\hline & 7 & 93 & 92 \\
\hline & 10 & 108 & 120 \\
\hline \multirow{4}{*}{ 2. T-1500 yağı distillatında } & 4 & 72 & 70 \\
\hline & 5 & 75 & 73 \\
\hline & 7 & 87 & 84 \\
\hline & 10 & 90 & 87 \\
\hline \multirow{4}{*}{ 3. T-30 yağı distillatında } & 4 & 85 & 82 \\
\hline & 5 & 88 & 83 \\
\hline & 7 & 92 & 90 \\
\hline & 10 & 118 & 115 \\
\hline
\end{tabular}

Cədvəldən göründüyü kimi yă̆ hazırlanmış konservasiya mayesi nisbətən distillatlarının dəyişməsi nəticəyə az təsir edir. yüksək müdafiə effektinə malikdir. Ogər müqayisə edilsə, T-46 yağı distillatında

Cədvəl 2. Nonilfenolun hidroksil qrupu saxlayan Ba duzunun mineral yağlarda məhlullarının konservasiya mayesi kimi sinaqlarının nəticələri

\begin{tabular}{|l|c|c|c|}
\hline \multirow{3}{*}{ Kompozisiyalar } & $\begin{array}{c}\text { Duzun qatılı̆̆ } 1, \% \\
\text { kütlə }\end{array}$ & Korroziyadan müdafiə müddəti, sutka \\
\cline { 3 - 4 } & 4.0 & Dəniz suyunda & $\begin{array}{c}0.001 \%-l i \mathrm{H}_{2} \mathrm{SO}_{4} \\
\text { məhlulunda }\end{array}$ \\
\hline \multirow{3}{*}{ 1. T-46 yağında } & 5.0 & 100 & 96 \\
& 7.0 & 110 & 98 \\
& 10.0 & 125 & 106 \\
\hline
\end{tabular}




\begin{tabular}{|l|c|c|c|}
\hline \multirow{3}{*}{ 2. T-30 yă̆ında } & 4.0 & 102 & 100 \\
& 5.0 & 107 & 103 \\
& 7.0 & 111 & 108 \\
& 10.0 & 131 & 127 \\
\hline \multirow{3}{*}{ 3. T-1500 yağında } & 4.0 & 88 & 86 \\
& 5.0 & 93 & 91 \\
& 7,0 & 106 & 102 \\
& 10,0 & 116 & 111 \\
\hline \multirow{3}{*}{ 4. AK-15 yağında } & 4.0 & 94 & 120 \\
& 5.0 & 125 & 128 \\
& 7.0 & 137 & 141 \\
\hline
\end{tabular}

Ba duzunun T-1500, T-30 və AK-15 yağlarında $4, \quad 5$ və $7 \%$-li məhlulları konservasiya mayesi kimi Q-4 hidrokamerasında da yoxlanılıb və aşağıdakı müdafiə müddətləri (sutka) müəyyən edilib:

T-1500 yağında 4,5 və $7 \%$-li məhlullar: uyğun olaraq 120, 150 (davam edir), 150 (davam edir) sutka.

T-30 yağında 4 və 7\%li məhlullar: uyğun olaraq 150, 150 (davam edir) sutka.

AK-15 yağında 4,5 və 7\%-li məhlullar: uyğun olaraq 142, 150 (davam edir) sutka.

Göründüyü kimi qatılıq 4\% olduğu halda ən yaxşı nəticə T-30 yağında olan məhlul daha yüksək müdafiə qabiliyyətinə malikdir.

Cədvəldən göründüyü kimi istifadə olunan mineral yağlarda hazırlanmış konservasiya mayeləri həmin yağların distillatlarında hazırlanmış konservasiya mayelərindən daha güclü müdafiə effektinə malikdir. Məsələn, tərkibində 4.0\% Ba duzu olan T-46 yağı distillat1 polad-3 nümunəsini dəniz suyunda 93 sutka, $0.001 \%$-li $\mathrm{H}_{2} \mathrm{SO}_{4}$ məhlulunda 90 sutka müdafiəni təmin etdiyi halda, T-46 yağının özündə hazırlanmış konservasiya mayesi eyni qatılıqda uyğun olaraq 98 və 96 sutka müdafiəni təmin edir. Götürülmüş 4 mineral yağdan ikisində - T-30 və AK-15 yağında müdafiə effekti daha yüksək olmuşdur.

Qeyd edək ki, distillatlarda müdafiə effektinin xeyli az olması onların tərkibində hirqoskopik xassəli aromatik karbohidrogenlərin miqdarının çox olması ilə izah edilə bilər. Belə ki, atmosfer nəminin müdafiə örtüyü tərəfindən udulması metal səthində korroziya prosesinin getməsi üçün əlverişli şərait yaradır. Havada olan aqressiv komponentlər su iştirakı ilə turş mühit yaradır və metal səthi daha çox korroziyaya uğrayır.

\section{NəTICO}

1. Konservasiya mayeləri hazırlamaq üçün mineral yağların distillatları yox, onların özlərini götürmək daha məqsədə uyğundur.

2. Nonil fenolun formaldehid ilə kondensləşmə məhsulunun barium hidroksid duzu əsasında konservasiya mayelərini

yaratmaq olar.

3. Nonil fenolun formaldehid ilə kondensləşmə məhsulunun Ba duzun AK-15 yağında məhlulu digər mineral yağlarda olduğundan daha yüksək müdafiə qabiliyyətinə malikdir.

\section{REFERENCES}

1. Abbasov V.M., Hany M.Abd El-Lateef, Aliyeva L.İ., İsmayılov İ.T., Mai M. Khalaf. İnhibitive performance of sulfated fatty acid sodium salt as corrosion inhibitor for carbon steel in $\mathrm{CO}_{2}$-saturated solutions. Azarbaycan Texniki Universiteti. Elmi Osarlar- Scientific works, 2012, vol. X (42), no.2, pp.176-183. (İn Azerbaycan). 
2. Abbasov V.M., Hany M.Abd El-Lateef, Aliyeva L.İ., İsmayılov İ.T. Application of Sopme Surfactants Based Pn Corn Oil As Corrosion İnhibitors for Carbon Steel in $\mathrm{CO}_{2}$ Environments. NACE corrosion. 2013, Florida, USA, paper no. 2129, pp.1-10.

3. Aghazade Y.J. The synthesis of amidoamines and nitro-compounds and their study as the components of the conservation liquids. Processes of Petrochemistry and Oil Refining. 2013, no.1, pp. 40-44.

4. Migahed M.A., Azzam M.S., and Al-Sabagh A.M. Corrosion Inhibition of Mild Steel in 1 M Sulfuric Acid Solution Using Anionic Surfactant. Materials Chemistry and physics. 2004, vol. 85, pp. 276-279.

5. Кулиев A.M. Chemistry and technology of additives to oils and fuels. Leningrad. Himiya Publ., 1985, pp. 228-229. (In Russian).

\title{
BARIUM SALT PRODUCT CONDENSATION OF NONHIL PHENOL WITH FORMALDEHYDE AS A COMPONENT TO THE CONSERVATIVE LIQUIDS
}

\author{
N.Sh. Rzayeva \\ Acad. Y.H. Mamedaliyev Institute of Petrochemical Processes, ANAS \\ Khodjaly 30,AZ 1025, Baku, Azerbaijan; e-mail: nigar.rzayeva555@gmail.com
}

Ba salt was obtained from the condensation product of nonyl phenol with formaldehyde with addition of mineral oils and their distilates. Conservation compositions were prepared which had subsequently been tested in a hydrocamera, sea water and $0.001 \%$ solution of H2SO4 and on steel-3 specimen to indentify the protective efficacy degree from corrosion. As the main component, distillates T-46, T-30, T-1500 and $A K-15$, as well as appropriate mineral oils were used. It revealed that the highest result is observed when using AK-15 oil. Experiments showed that a conservation liquid consisting of $90 \%$ of AK-15 and $10 \% \mathrm{Ba}$ salt ensures protection against atmospheric corrosion in a buffer liquid, sea water and $0.001 \%$ p-pe $\mathrm{H}_{2} \mathrm{SO}_{4}$ for 150, 145 and 141days.

Keywords: atmospheric corrosion, conservation liquids, mineral oils, alkyl phenols, nonhil phenol, condensation products of alkyl phenols with formaldehyde

\section{БАРИЕВАЯ СОЛЬ ПРОДУКТА КОНДЕНСАЦИИ НОНИЛФЕНОЛА С ФОРМАЛЬДЕГИДОМ В КАЧЕСТВЕ КОМПОНЕНТА К КОНСЕРВАЦИОННЫМ ЖИДКОСТЯМ}

\author{
H.H. Рзаева
}

Институт Нефтехимических проиессов Национальной АН Азербайджсана AZ1025, Баку, Пр.Ходжаль 30; e-mail:nigar.rzayeva555@gmail.com

Получена бариевая соль продукта конденсаиии нонилфенола с формальдегидом, добавлением ее к минеральным маслам и их дистилатам приготовлены консервационные составы, которые в дальнейтем протестированы в гидрокамере, морской воде и 0.001\%-ом р-ре $\mathrm{H}_{2} \mathrm{SO}_{4}$ на образие стали-3 для определения степени защиты от коррозии. В качестве основного компонента использованы дистиллаты T-46, T-30, T-1500 и АK-15, а также соответствуюшие минеральные масла. Установлено, что самый высокий результат наблюдается при использовании масла АК15. Эксперименты показали, что консервационная жидкость, состоящая 90\% из AK-15 и 10\% бариевой соли, обеспечивает защиту от атмосферной коррозии в гидрокамере, морской воде и $0.001 \%$ р-ре $\mathrm{H}_{2} \mathrm{SO}_{4}$ 150, 145 и 141 суток соответственно.

Ключевые слова: атмосферная коррозия, консервационные жидкости, минеральные масла, нонилфенол, продукты конденсаиии нонилфенолов с формальдегидом. 